\title{
Tempus og aspekt med sarligt henblik på italiensk
}

\author{
SVEND BACH \\ Romansk Institut, Aarhus Universitet, Danmark
}

This paper intends to discuss some fundamental issues regarding tense and aspect in connection with a presentation of the Italian system of morphologically marked distinctions within the categories of tense and aspect; but it is also intended as a basis for studies in the function of tense and aspect in literary narrative (a matter to which I have dedicated the studies mentioned in the list of references). However, my main view is that inscribing presumed textual functions into the general definitions of morphemes (along the lines originally indicated by Benveniste and Weinrich), does not contribute to our understanding of texts, but will rather create obstacles for it. In fact I can see no valid alternative to describing tense in terms of 'time'. As others before me, I divide tenses in two groups on the basis of the distinctive semantic feature [+/-past]; Italian has two simple tenses in each group, and - corresponding to each of the four simple tenses - compound tenses formed with an auxiliary + the perfect participle, and semantically characterized by the fact that they signify a state as a consequence of an anterior state, process or event signified as aspectually perfective. Compound tenses are thus morphologically as well as semantically complex: they differ with regard only to the tense and aspect of the 'consequence level' as expressed by the form of the auxiliary. This means that each tense, even the compound ones, are defined without taking into account a 'point of reference' or similar concepts: compound tenses express in themselves temporal location thanks to their auxiliary verb. Such semantic complexity is of particular importance in the case of the present perfect and the past perfect, both of which have two typical uses according to the predominance of the consequence level signified by their auxiliary or to the state/ process/event signified by their lexeme (i.e. the past participle). This view entails an almost complete symmetry between these two tenses, and seems apt to solve a series of problems, especially concerning the use of the past perfect, some of which posed by other scholars. It is also confronted with the problems of consecutio temporum. I stress the fact that the basic distinctive features belong to the semantic level, and do not necessarily correspond to extralinguistical evidence in any instance of the use of a certain form. Thus the presumed "imperfective use" of the perfects is seen as an instance of confusion between semantics and extralinguistic reality. In the final part I mention 'figurative use' as the most important factor to create deviance between the semantics of forms and particular instances of temporal reference; I propose a distinction between metonymic and metaphoric uses, corresponding to different degrees of referential deviance from the basic semantic content of the forms. 


\section{INDLEDNING}

Min interesse for tempus og aspekt er dels af generel art, dels retter den sig specielt mod hvad disse sproglige kategorier kan bruges til i litterære fortællinger. Jeg mener at studiet heraf kan bidrage til at skabe indsigt i noget væsentligt i sproget såvel som i litteraturen.

En analyse af tempusbrug i narrative tekster bør dog efter min mening bygge på almene definitioner af de former der findes i det pågældende sprogsystem, således at definitionerne er gyldige for en hvilken som helst tekst og kontekst hvori de måtte forekomme. Virkninger af tempus og aspekt der opstår i bestemte teksttyper eller i konkrete kontekster, bør derimod ikke indskrives i de enkelte bøjningsformers semantik. Det er disse overordnede lingvistiske problemstillinger jeg hovedsagelig vil koncentrere mig om i det følgende. Spørgsmålet om hvordan man kan gribe analysen af tempuskategoriens funktion i litterære fortællinger an, bliver jeg desværre nødt til at lade ligge i denne sammenhæng. ${ }^{1}$

Af hensyn til ikke specielt italienskkyndige benytter jeg her termerne 'præsens', 'futurum', 'futurum exactum', 'imperfektum', 'perfektum' (sv. til 'førnutid') og 'pluskvamperfektum'. Derimod holder jeg fast i den italienske betegnelse 'passato remoto' om den usammensatte, aspektuelt perfektive fortidsform. De italienske eksempler er alle oversat til dansk, på en måde der holder sig nogenlunde tæt til originalernes syntaks, herunder også deres tempusbrug. Hvor der i oversættelserne er brugt dansk præsens, perfektum og pluskvamperfektum, er det (medmindre andet er anført) underforstået at de svarer til de italienske former med samme benævnelse. De usammensatte fortidstempora er i oversættelserne markeret som "[p.r.]" (passato remoto) eller "[imp.]" (imperfektum), således at det bliver tydeligt hvilken italiensk form der svarer til en dansk præteritum. De danske gengivelser af andre italienske former end de nævnte markeres på tilsvarende måde.

\section{KAN TEMPUS DEFINERES UD FRA TEKSTFUNKTIONER?}

Det synspunkt jeg har fremsat ovenfor, nemlig at definitionerne af de enkelte tempora bør være generelt gyldige og ikke bygge på eller inkludere virkninger der kun opstår i visse kontekster, indebærer at jeg for det første må forholde mig skeptisk til positioner af den art som Weinrich og Benveniste står som eksponenter for. Weinrich (1964/1971) deler som bekendt tempora i to grupper efter den afsenderholdning de signalerer: de "fortællende" og de "kommenterende" tempora (hhv. "erzählende Tempora" og "besprechende Tempora"). Denne teori rummer i sig det uløselige problem der følger af at såkaldt fortællende tempora er uhyre almindelige i sammenhænge der ikke med nogen rimelighed kan betegnes som fortællende, ligesom omvendt specielt præsens, der skulle være et kommenterende tempus, længe har været uhyre almindelig som bærer af en regulær fortælling (jf. Petersen 1992). Man får det indtryk at "fortælling" for Weinrich først og fremmest er ensbetydende med folkeeventyr, medens de typer fortællinger hvori præsens spiller en stor rolle, repræsenterer et forfald, en fordærvet fortælleform, der ikke fortjener videnskabens opmærksomhed.

Weinrich siger bl.a. at "fortælletempora" modsat de "kommenterende" tempora 
signalerer en afslappet holdning. ${ }^{2}$ Men er man mere afslappet under læsningen af en kriminalroman end når man læser $\mathrm{fx}$ en afhandling om havebrug eller om Jupiters måner? I eksempel (1) fremstilles en person der nærmest falder besvimet om blot ved at høre en fortidsform:

1a) "colui ch'attende là, per qui mi mena, forse cui Guido vostro eb be a disdegno."

$[\ldots]$

"Di subito drizzato gridò: 'Come dicesti? elli ebbe'? non viv'elli ancora? non fiere li occhi suoi lo dolce lume?' Quando s'accorse d'alcuna dimora ch'io facea dinanzi alla risposta supin ricadde e più non parve fora." (Dante, Inferno X, 62-63 og 67-72)

1b) "[...] min fører venter dér - måske han kan lede mig til en som Guido vraged [p.r.]." [...] "Han rejste sig med ét, og råbte: 'Vraged [p.r.]? Hvad sagde du? Lever han da ikke mere? Og rammer lyset ikke mer hans øjne?' Og da han så min tøven før jeg svared, sank han på ny tilbage ned i kisten."

(Ole Meyers oversættelse)

Den døde sjæl i Helvede, digteren Guido Cavalcantis fader, spørger Dante hvorfor han har brugt fortidsformen ebbe; og da Dante ikke umiddelbart svarer på det, bryder han sammen i fortvivlelse. ${ }^{3}$

Ligeså uhensigtsmæssigt er det at tilskrive de to usammensatte fortidstempora på de romanske sprog en generel værdi som markører af henholdsvis forgrund og baggrund (jf. Weinrich 1964/1971: 95). Det er ganske vist en velkendt, men, som det fremgår af (2), ingenlunde en nødvendig virkning:

2a) Il mondo esterno? Be', ci giungeva attraverso Andrea il postino. Aveva cominciato come portalettere distrettuale nel 1882 [...] dal 1884 er a impiegato presso l'ufficio postale di Holstebro e a questo face va capo finché la ferrovia non a rrivò nel 1904 con stazione e ufficio postale a Tvis, dove allora fu trasferito.

Questi a veva un giro lungo quanto il dì e da casa sua alla stazione c'e ra no due miglia circa di strada che faceva in soprappiù. Alla scuola arriva va che erano le due o le tre ed io spesso mi mettevo fuori per vederlo: infatti proce deva caracollando attraverso i campi di Søren Skavtrup. Non era il tipo che si fermava a chiacchierare, ma siccome giungeva spesso all'ora del caffe pomeridiano, si concedeva una piccola sosta. Andrea il postino reca va lettere, giornali e riviste. Io e ro abbonato al "Corriere dei ragazzi" che in iziò ad uscire nel 1904, e lì uno poteva seguire con passione la guerra russo-giapponese.

2b) Verden udenom? Jo, den kom [imp.] til os med Anders Post. Han var begyndt som landpost 1882 [...] fra $1894 \mathrm{var}$ [imp.] han ansat ved postkontoret i Holstebro og gik [imp.] ud derfra, indtil banen kom [p.r.] i 1904 med station og postkontor i Tvis, hvortil han så blev forflyttet [p.r.]. 
Han gik [imp.] den daglange tur og havde [imp.] fra sit hjem ved Vinding skel cirka 3 fjerdingvej til stationen - altså ca. halvanden mil at gå ekstra uden for postturen.

Til skolen kom [imp.] han ved 2-3 tiden - jeg var [imp.] tit ude at se efter ham, når han kom duvende [imp.] skridt for skridt ned over Søren Skavtrups agre. Han var [imp.] ikke unødigt snakkende, men da det ofte var ved kaffetid han kom [imp.], kunne han godt unde sig [imp.] et lille hvil. [...]

Anders Post kom [imp.] med breve, avis (Holstebro Dagblad) og blade (Folkeskolen). Jeg holdt [imp.] Børnebladet (Christian Eriksen), der begynd te [p.r.] at komme 1904, og her lae ste [imp.] man med spoending om den russisk-japanske krig (190405).

(Peter Skautrup, Hørt og husket, pp. 72-73)

Hvis begreberne forgrund og baggrund skal have nogen mening, er det her forgrundsplanet der står i imperfektum, og baggrundsplanet der står i passato remoto. ${ }^{5}$ Således i slutningens iniziò ('begyndte'), men også det indledende afsnits fortællende oplysninger er underordnet de følgende beskrivende afsnit i iterativ imperfektum. Trods den enerådende brug af "fortælletempora", er passagen nemlig ikke fortællende (i gængs forstand).

Benveniste (1959) foretager en i hovedtræk lignende todeling af tempussystemet, idet han mener at nutids- og fremtidstempora tilhører fremstillingsformen "discours", hvor afsender og modtager er engagerede, i modsætning til "histoire" (også kaldet "récit"), der som objektiv fremstillingsform giver indtryk af at teksten så at sige "har skrevet sig selv". Idéen virker på forhånd dødfødt: krumtappen i den er at passé simple er en entydigt objektiv form; men derved forbliver det uafklaret hvordan man skal forholde sig til tekster der er udformet i passé simple, men i 1. person. ${ }^{6}$ Man kunne også spørge om fx videnskabelige afhandlinger i præsens er mere personlige og subjektive end historieskrivning i fortidstempora.

\section{Definition Af Formerne I Det ITALIENSKE TEMPUSSYSTEM VED hJÆELP AF SEMANTISKE TRAEK}

Jeg kan erklære mig enig med Weinrich og Benveniste i at tempussystemerne i italiensk såvel som i mange andre sprog med fordel kan deles i to grupper. Men jeg har ikke set noget brugbart alternativ til at definere disse som markeringer af tidsforhold og altså som 'fortids-' og 'ikke-fortidstempora'. Det italienske system opstilles efter min mening bedst som følger:

\begin{tabular}{|c|c|c|c|c|}
\hline \multirow{5}{*}{ Aspekt } & & \multicolumn{3}{|l|}{ Tempus } \\
\hline & & \multirow{2}{*}{ [+fortid] } & \multicolumn{2}{|c|}{ [-fortid] } \\
\hline & & & [-fremtid] & [+fremtid] \\
\hline & [+afgrænset] & Passato remoto & & Futurum \\
\hline & [-afgrænset] & Imperfektum & Proesens & \\
\hline
\end{tabular}

NB. Præsens kan tilskrives trækket [-afgrænset]; futurum er aspektuelt neutral, dvs.

[+/-afgrænset]; disse træk er ikke distinktive, men dog antydet i skemaet. 
Hermed er de usammensatte former defineret indbyrdes ved hjælp af semantiske træk, således at de tilskrives en værdi som de ifølge min teori altid har, uanset hvilken kontekst de står i. Alle de virkninger af tekstlig, pragmatisk, retorisk og kognitiv art der alene opstår som (forudsigelige) konsekvenser af samspillet med nærmere bestemte kontekster, er derimod ikke medtaget.

Til de usammensatte tempora svarer der ligesom på andre romanske og på germanske sprog sammensatte tempora dannet med hjælpeverbum + perfektum participium. Jeg vender tilbage til dem i det følgende, specielt §§ 5.2 og 6-7.

Hertil kunne man føje en række aspekt-perifraser, specielt stare + gerundium, der kan minde om de udvidede tempora med be + -ing-form på engelsk, men som i italiensk har en væsentlig mere indskrænket brug. Jeg skal ikke komme nærmere ind på dem her.

Fortids fremtid har ikke noget selvstændigt udtryk, men er en betydning der opstår kontekstuelt når en sammensat konditionalis (eller imperfektum) er syntaktisk eller blot semantisk afhængig af et (evt. implicit) ytrings- eller tankeverbum.

\section{HVAD MARKERER TEMPUS TID I FORHOLD TIL?}

Det har længe været en udbredt praksis at indskrive Reichenbachs 'point of speech', 'point of event' og 'point of reference' el. lign. i temporaenes definitioner. Det sidstnævnte vil blive behandlet i § 5. 'Point of speech' er ekstratekstuelt givet, og 'point of event' svarer til de i § 3 fremlagte definitioner af de enkelte tempora; men begge disse begreber bruges på en ofte problematisk måde, hvorfor jeg må indføre nogle præciseringer:

Kommunikationstidspunktet, som jeg herefter vil betegne som 'nutidsaksen', er det som alle tempusmarkeringer relaterer til (jf. dog § 8). Men der er grund til at understrege at det, når man har at gøre med skrevne tekster, ikke nødvendigvis er lig det tidspunkt hvor teksten er udformet (som beskrevet i Bach 1998/2000: 156157 og Skårup 2001: 207-208). Da der jo er mærkbar afstand mellem afsendelsesog modtagelsestidspunktet, kan det sidstnævnte være det afgørende, således fx i avisartikler, i metatekstuelle udsagn (af typen "Vi vil vende tilbage til dette i kap. X"), i regibemærkninger i skuespil. I alle disse tilfælde lægger afsenderen fremstillingen til rette således at m od t a g e r en kan opfatte præsens som refererende til sin egen nutid, fortidstempora til fortid osv. Det samme kan spille en rolle ved brugen af historisk eller dramatisk præsens i fortællinger, hvor det nutidige kan synes afsenderbetinget (emotivt for at bruge Jakobsons term) eller modtagerbetinget (nemlig når afsenderen lægger fremstillingen til rette med henblik på at frembringe bestemte virkninger ved afkodningen). I fiktion er der yderligere det problem at det reelle nedskrivningstidspunkt er irrelevant. Her er det den principielt fiktive fortællers nutid der er det afgørende. Denne fortæller kan slette sporene af sin tilstedeværelse; men det er ikke ensbetydende med at afsenderinstansen mangler, dvs. at fx fortidstempora ikke markerer fortidighed. Det er således irrelevant for tempusbrugen i Orwells 1984 at bogen udkom i 1948. Noget andet er at effekten af fortidstempora bliver mindre i fortællinger der ikke skaber kontrast mellem nutid (fortælletiden) og fortid (den fortalte tid). 
Verbalhandlingens lokalisering i tiden. Jeg finder det afgørende vigtigt at skelne mellem den måde hvorpå den sproglige mening ${ }^{7}$ præsenteres ved hjælp af tempus, og lokaliseringen af dens virkelighedskorrelat i en subjektivt oplevet tid eller i en objektiv tid. Herslund (1987) mener fx at brugen af fortid i en sætning som (3) (her gengivet på dansk)

\section{3) I Ijor mødte jeg en smuk enke. Hun havde to døtre}

udgør et problem ifald den pågældende objektivt set stadig har to døtre på kommunikationstidspunktet. Men det er svært at forestille sig nogen tolkning af (3) der ikke går ud på at tilstanden præsenteres som fortidig, dvs. som noget der ikke vedrører den talendes eller modtagerens - i tidslig forstand - aktuelle virkelighed. I dette tilfælde er tempusmarkeringen i overensstemmelse med en subjektiv tid; de objektive kendsgerninger vedrørende sagsforholdets fortsatte beståen eller ikke beståen i nutiden forekommer irrelevante.

En præsens i (3) ville angive 'aktualitet på kommunikationstidspunktet', men uden dermed at udelukke sagsforholdets gyldighed i fortiden. Dette forhold, som fx inklusiv brug af præsens illustrerer (i udtryk som Studia da tre anni, 'Han har studeret i tre år'), er ikke i konflikt med definitionen, men tværtimod noget typisk..$^{8}$ I modsætning til mange finder jeg derfor at der er fuld overensstemmelse mellem definitionen af præsens og formens "tidløse" brug; det drejer sig under alle omstændigheder om verbalhandlinger hvis lokalisering omfatter nutidsaksen.

Man finder også kortslutninger mellem sprog og virkelighed i forbindelse med aspekt. Fx er det en udbredt opfattelse at udtryk som (4)

4a) È sempre stato un buon compagno

4b) Han har altid voeret en god kammerat

repræsenterer en imperfektiv brug af den sammensatte verbalform. Argumentet er at tilstanden må formodes at fortsætte også ud over nutidsaksen. Men i så fald må man også acceptere at passato remoto har imperfektive anvendelser, fx

5a) Per tutta quell'estate soggi orna rono a Viareggio, e non si mossero di lì quando venne l'autunno

5b) Hele den sommer opholdt de sig [p.r.] i Viareggio, og de tog ikke af sted da det blev efterår

6a) Il cane voleva scappare, ma il padrone lo tenne fermo

6b) Hunden ville stikke af, men dens herre holdt [p.r.] den fast

Hvis man argumenterer ud fra den ekstrasproglige virkelighed som der refereres til, synes alle betingelser at være til stede for at regne med imperfektiv værdi i eks. (4)(6). De pågældende tilstande fortsætter jo uden afbrydelse, og såvel deres begyndelse som deres slutning er helt uspecificerede. Men den perfektive form må i eks. (4) og (5) tolkes sådan at verbalhandlingen præsenteres som en 'status' over en afgrænset periode, uden på nogen måde at udelukke at den tilstand der refereres til i den ekstrasproglige virkelighed, fortsætter ud over afgrænsningen. Hvis perfektum havde imperfektiv værdi i (4), ville det i øvrigt være vanskeligt at forklare den betydningsændring som 
en udskiftning med præsens ville medføre. M.h.t. (6) henvises til Bach/Schmitt Jensen (1990, § 325.2).

\section{5. 'POINT OF REFERENCE'}

Reichenbachs 'point of reference' e. lign. er utvivlsomt et nødvendigt instrument for analysen af de virkninger der opstår når flere tidsudtryk (verbalformer og adverbialer) arbejder sammen i en tekst. Det forekommer mig derimod irrelevant for formernes definitioner.

\subsection{USAMMENSATTE TEMPORA}

Imperfektum betegner således blot verbalhandlingen som uafgrænset og lokaliseret før nutidsaksen. Der behøver ikke foreligge nogen relation til andre fortidstempora eller til adverbialer. Trækket [-afgrænset] udelukker heller ikke at verbalhandlingen kan være anskuet "udefra", fx som karakteristik af en entitet (person, genstand, tidsrum osv.). Der kan fx være tale om en tilstand der er afbrudt kort før nutidsaksen, fx

7a) Forse dovrei rifarmi la barba. Sì, dovrei rifarmela, ma [...] lascio ricadere le dita che saggia vano la guancia [...] (Del Buono, Un minimo di pietà, in: Novelle italiane. Il Novecento (Garzanti) p. 906)

7b) Måske skulle jeg barbere mig igen. Ja det skulle jeg gøre, men ... jeg lader fingrene, der følte [imp.] på kinden, glide ned

Hvis der derimod er en relation til andre markeringer af fortidighed, er der typisk tale om samtidighed, ikke mindst i form af imperfektums aspektuelle modsætning til passato remoto. Kombinationen passato remoto + imperfektum vil ofte give den virkning at en tilstand eller proces opfattes som allerede foreliggende på det tidspunkt hvor en begivenhed indtræffer. Men imperfektum kan også præsentere en tilstand der må forstås som successiv (eventuelt en fortids fremtid) eller som førfortidig. I det følgende eksempel er der endog tale om lokalisering før en verbalhandling i pluskvamperfektum (hvilket tydeligt fremgår af den større kontekst):

8a) Alle sette e trenta era suonata la sveglia: l'ora in cui lei si alzava quando insegna va alla scuola materna (Crovi, Amore di domenica p. 165)

8b) Klokken 7.30 havde voekkeuret ringet: det var det tidspunkt hvor hun stod op [imp.] da hun underviste [imp.] i børnehaven

Tilsvarende markerer passato remoto blot verbalhandlingen som afgrænset og lokaliseret før nutidsaksen. Også denne form kan bruges isoleret og uden støtte i adverbielle angivelser. En verbalhandling i passato remoto er af sin natur egnet til at fungere som 'point of reference' for andre verbalformer, men den kræver ikke selv noget.

Det skal indrømmes at man i praksis som modtager næsten altid vil have en forestilling om hvor i fortiden en verbalhandling skal lokaliseres. Derimod vil en futurum ofte præsentere en fremtidig verbalhandling hvis mere præcise lokalisering hverken afsender eller modtager har nogen viden om, hvilket er et yderligere argument for ikke at opstille et system der kræver indskrivning af 'point of reference' el. lign. i formernes definition. 


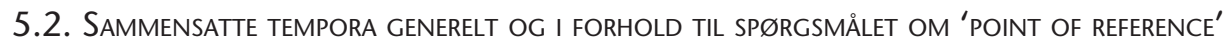

De sammensatte tempora er både morfologisk og semantisk sammensatte: de er dannet af hjælpeverbum + perfektum participium, og de udtrykker konsekvensen af en handling der har fundet sted. Ligesom de morfologisk har participiet til fælles, har de semantisk det fælles træk [+afgrænset]; og ligesom de adskiller sig indbyrdes ved hjælpeverbets form, beror de semantiske forskelle mellem dem på de samme forskelle som dem der gælder de usammensatte tempora, idet 'konsekvenstilstanden' er lokaliseret og [+/-afgrænset] som angivet af hjælpeverbet.

Definitionen implicerer en dobbelt symmetri mellem præsens, imperfektum, perfektum og pluskvamperfektum, idet alle disse fire tempora betegner en uafgrænset situation, nemlig enten den i leksemet udtrykte verbalhandling (præsens og imperfektum) eller dens konsekvens (perfektum og pluskvamperfektum); og den uafgrænsede situation er enten nutidig (præsens og perfektum) eller fortidig (imperfektum og pluskvamperfektum). En symmetri mellem anvendelser af imperfektum og pluskvamperfektum ser vi fx i (citeret fra Bach /Schmitt Jensen 1990, § 341 og § 345.3):

9a) Dunque, dicevo: adesso ci farebbe piacere di conoscere meglio voi (Edoardo De Filippo, Gli esami non finiscono mai)

9b) Men altså, jeg sagde [imp.] at nu ville det gloede os at loere Dem bedre at kende

10a) Avevamo detto di telefonare

10b) Vi havde sagt at man skulle telefonere

Disse eksempler ${ }^{9}$ illustrerer brugen af imperfektum og pluskvamperfektum ved genoptagelse af en afbrudt ytring. Det er ud fra disse formers definition umiddelbart indlysende hvorfor de kan fremkalde denne virkning; den talende knytter an til en uafgrænset fortidig handling der har været afbrudt som i (9), eller til en stedfunden handling hvis konsekvenser, fx som følge af andre indtrufne begivenheder, er ophørt som i (10). Eks. (11), ibid. § 345.3, illustrerer virkningen 'afbrudt handling eller konsekvenstilstand' med andre typer verber:

11a) Giovanni: Non mi aspettavo [imp.] addirittura una visita.

Tomaso: T'avevamo scritto, più d'una volta.

(Ugo Betti, L'aiuola bruciata I,2)

11b) G.: Jeg ventede ikke ligefrem et besøg.

T.: Vi havde skrevet til dig flere gange.

Da Tomaso nu står foran Giovanni, er dennes manglende forventning om hans besøg naturligvis ikke længere aktuel: non mi aspettavo betegner en afbrudt handling. Tilsvarende betegner T'avevamo scritto i Tomasos svar en handling der har fundet sted, men hvis konsekvenser ikke mere er aktuelle i situationen.

De sammensatte temporas dobbelte tidsmarkering er i princippet impliceret af en hvilken som helst brug af dem; men i perfektum og pluskvamperfektum kan den ene side dominere alt afhængigt af konteksten. Hermed făr man to typiske kontekstuelle varianter af hver af de to tempora: én hvor vægten ligger på konsekvenstilstanden, og én hvor vægten ligger på den forudgående, afgrænsede verbalhandling, ${ }^{10}$ men også med mulighed for en relativ ligevægt mellem de to betydningskomponenter. At perfektum har sådanne to varianter, er velkendt, men pluskvamperfektum opfører sig helt samme 
måde. En serie verber i perfektum eller pluskvamperfektum vil således fremkalde vægt på det perfektive, dog forudsat der er tale om handlinger der lægger op til en kronologisk ordning, og især når hver afsluttet handling udgør en følge eller reaktion i forhold til den foregående, eller en fortsættelse af den, ligesom når man har at gøre med en fortælling i passato remoto. En perfektum der indgår i en serie af præsensformer, vil derimod normalt have vægt på det den har til fælles med præsens, og fx indgå $\mathrm{i}$ beskrivelsen af en nutidig situation; tilsvarende indgår pluskvamperfekta, i tekstpassager der overvejende er holdt i imperfektum, i beskrivelsen af en fortidig situation. I (12) indgår de første perfekta i beskrivelsen af en nutidig situation i fortsættelse af det indledende verbal i præsens, de følgende (fra Poi ..., 'Derpå') danner et fortidigt handlingsforløb hvor perfektum kontrasterer aspektuelt med imperfektum:

12a) Il sole è alto sulle case di via del Corno. Le sveglie si sono ritrovate al loro appuntamento mattutino. Otello ha aperto la carbonaia, Maciste ha governato il suo cavallo. [...] Carlino ha det to a sua madre che stamani non an drà in ufficio. Poi è sceso per informare il Nesi che la Signora è sotto la sua protezione [...] Il Nesi è rim as to basito, nel fondo della carbonaia: sma ni a va come gli mancasse il respiro. (Pratolini, Cronache di poveri amanti, kap. V in fine)

12b) Solen står allerede højt over via del Corno. Voekkeurene har afliret deres soedvanlige morgenhilsen. Otello har åbnet kulhandelen. Maciste har sørget for sin hest. [...] Carlino har sagt til sin moder, at han ikke går [fut.] på kontoret til morgen. Derpå er han gået ned for at underrette Nesi om, at Signora'en står under hans beskyttelse. [...] Nesi blev [perf.] ganske målløs, dernede i sin kulkaelder; han rasede [imp.] som om han ikke kunne få vejret. (oversat af Bodil Anker Larsen og Carmen Zimmer, med enkelte ændringer)

Dette spektrum af anvendelser - på basis af samme grundværdi - gør den italienske (og franske) perfektum meget forskellig fra fx den danske (og engelske).

I de fleste tilfælde er det muligt at lokalisere en pluskvamperfektums konsekvenstilstand ved hjælp af adverbialer eller andre verbalhandlinger i konteksten; men det er, ligesom for imperfektums vedkommende, ikke nogen absolut nødvendighed, og altså ikke nogen grund til at indskrive et 'point of reference' i formens definition. Sammensatte temporas konsekvenstilstand er allerede lokaliseret i kraft af de informationer der ligger i hjælpeverbet.

Ducrot (1995) definerer tempora ved hjælp af begrebet 'thème temporel', der er inspireret af Reichenbach, men også refererer til tema i forhold til rema. Ducrots begreb forudsætter ikke fokalisering af et pun kt i tiden (der kan være tale om et udstrakt og vagt afgrænset tidsrum), hvad der forekommer at være en nyttig præcisering. De sammensatte tempora skulle være karakteriseret ved at handlingen ligger forud for 'thème temporel', de usammensatte ved sammenfald eller overlapning. Ducrot må dog tage forbehold m.h.t. perfektum, og burde have gjort det samme for pluskvamperfektums vedkommende. Begge kan faktisk betegne en handling der falder sammen med 'thème temporel', og gør det ofte, hvad den første sætning i eks. (8) illustrerer for italiensk pluskvamperfektum. Herved bliver det opstillede kriterium utilstrækkeligt, idet man højst kan sige at sammensatte tempora i modsætning til usammensatte ka n betegne en handling der ligger forud for 'thème temporel'; men to 
af dem kan altså også betegne tid på s a m m e måde som usammensatte. ${ }^{11}$

\section{En behandling af pluskVamperfektum: Vegnaduzzo (1997)}

Der kan konstateres en vis lighed mellem min opfattelse af sammensatte verbalformer og den der fremsættes i Vegnaduzzo (1997). Han mener nemlig at et uspecificeret 'event' (meget lig det jeg kalder 'konsekvenstilstand') er præsupponeret indhold i selve formen, men dog kun ifald et 'point of reference' ikke kan identificeres i konteksten, og han generaliserer ikke synspunktet til andre sammensatte tempora end pluskvamperfektum (indikativ og konjunktiv). Om et sådant 'event' beror på præsupposition, skal jeg undlade at gå nærmere ind på, men Vegnaduzzo har i hvert fald ret i at der er tale om en betydningskomponent der kan bortfalde ved visse anvendelser af pluskvamperfektum konjunktiv. Således er formen rent imperfektiv i

13a) Sefosse stato ricco ...

13b) Hvis han havde voret rig...

der jo implicerer tilstanden non era ricco ('han var ikke rig'). Dette skyldes simpelthen den modale tempusforskydning, der indebærer at pluskvamperfektum overtager hele det spektrum af temporale og aspektuelle værdier der ellers dækkes af imperfektum, passato remoto og perfektum. Også sammensat konditionalis samt modalt brugt futurum exactum dækker det selvsamme område, $\mathrm{fx}$

14a) Sarebbe stato felice

14b) Han ville have voeret [sms. kond.] lykkelig

15a) Sarà stato felice

15b) Han var sikkert [fut. ex.] lykkelig

Vegnaduzzo behander dog især de problemer der opstår når pluskvamperfektum ved gengivelse af ytringer i indirekte tale med styrende verbum i fortidstempus skal dække de betydninger der i direkte tale udtrykkes dels med perfektum, dels med passato remoto, dels med pluskvamperfektum. Af særlig interesse i denne sammenhæng er den påstand at pluskvamperfektum kun kan overtage perfektums anvendelser som deiktisk fortid i forhold til nutidsaksen, og ikke visse af formens mere specielle funktioner. Hvis dette er rigtigt, vil det i nogen grad reducere den symmetri jeg ovenfor har hævdet der findes mellem perfektum og pluskvamperfektum. Vegnaduzzo (1997: 353) mener fx ikke at man kan foretage følgende transponering med bibeholdelse af perfektums "atemporale" betydning (som jeg ikke vil anse for atemporal):

16a) È pericoloso rilasciare di nuovo la patente di guida ad un automobilista che ha inves tito delle persone guidando in stato di ubriachezza

16b) Det er farligt at genudstede et kørekort til en bilist der har påkørt nogen under kørsel $i$ beruset tilstand

17a) Lucio disse che era pericoloso rilasciare di nuovo la patente di guida ad un automobilista che aveva guidato in stato di ubriachezza

17b) Lucio sagde at det var farligt at genudstede et kørekort til en bilist der havde kørt $i$ beruset tilstand 
Her ville det dog være nok at ændre relativsætningens modus til konjunktiv for at sikre den non-specifikke betydning af korrelatet i (17a). Konjunktiv ville også være mulig - ved non-specifikt korrelat - i (16a), men synes påkrævet i (17a). En anden mulighed er at bruge en betingelsessætning i stedet: ved i (17a) at erstatte che med se (dansk 'hvis han ...') ville man få et generisk udsagn i pluskvamperfektum indikativ.

Vegnaduzzo mener endvidere at man ikke kan omsætte en perfektum der refererer til ekstrasproglig fremtid (jf. § 8.2.1) til pluskvamperfektum. Men ifald en passende sproglig kontekst kompenserer for den manglende situationskontekst, vil forståelsen af den ikke-bogstavelige betydning kunne sikres. Således vil ganske små ændringer kunne gøre nogle af Vegnaduzzos eksempler acceptable:

18a) Domani ho finito

18b) I morgen er jeg blevet foerdig

19a) *Lucio disse che domani aveva finito

19b) Lucio sagde at i morgen var han blevet foerdig

Her er det nok at skifte det deiktiske adverbial ud med et anaforisk:

20a) Lucio disse che l'indomani aveva finito

20b) Lucio sagde at noeste dag var han blevet foerdig

Et andet eksempel, der hos Vegnaduzzo gives i den form det har i (21a), kan vi modificere til (22a), der ligeledes modbeviser hans tese:

21a) *Lucio disse che prima di sera erano arrivati

21b) Lucio sagde at før aften var de nået frem

22a) Lucio disse che per le sette eravamo arrivati

22b) Lucio sagde at til klokken syv var vi nå et frem

\section{En ANDen tilgang til pluskvamperfektum og tempora Generelt: KorZen (2002)}

Korzen (2002), der knytter an til Herslund (1987, jf. § 4), mener generelt at man ikke bør definere tempus som udtryk for tid, men fx tilskrive pluskvamperfektum en 'deaktualiserende' værdi [-tekstaktuel], således at den markerer baggrundsinformation i en tekst. Han begrunder det med en række pragmatiske virkninger af dens brug, hvoraf de vigtigste dog svarer umiddelbart til dem jeg har illustreret ovenfor med eks. (9)-(11). Men også andre falder ind under samme forklaring og kan ses som eksempler på en afbrudt konsekvens, fx et der citeres fra Squartini (1999: 58):

23a) Chi avevi conosciuto, quando eri stata a Pisa?

23b) Hvem havde du mødt, da du var (egentlig: havde voeret) i Pisa?

Eksemplet er i sig selv - skønt det er konstrueret af en 'native speaker' - besynderligt, men interessant fordi det afslører en indgroet fordom hos italienske grammatikere, gående ud på at alle verbalhandlinger der angår førfortid, skal stå i pluskvamperfektum. Men i virkeligheden gælder dette kun verbalhandlinger der ønskes markeret for perfektivt aspekt; verbet i eksemplets ledsætning burde erstattes med en imperfektum. Det bliver da let at tolke eksemplet sådan at der, siden den adspurgtes ophold i Pisa, må 
være sket noget der har afbrudt konsekvenserne af det omtalte møde. Min udlægning ved hjælp af begrebet 'afbrudt konsekvens' fører for så vidt også til et resultat som man kunne kalde deaktualisering; blot således at jeg når frem til det uden at fravælge 'tid' som formens grundværdi.

Videre hævdes det at formen ikke nødvendigvis angiver førfortidighed, et synspunkt som forsøges underbygget med eks. (24):

24a) Bianchi ha perso l'aereo per Roma: er a arrivato tardi in aeroporto

24b) Bianchi nåede ikke (ordret: mistede [perf.]) flyet til Rom; han var ko mmet for sent til lufthavnen

Argumentet går på at det at "miste" flyet sker i det øjeblik hvor flyet afgår, hvorfor begivenheden era arrivato ('var kommet') i virkeligheden er successiv i forhold til ha perso ('mistede'), og ikke omvendt, sådan som en definition af pluskvamperfektum ud fra 'tid' ville indebære. Pluskvamperfektum skulle derfor forstås som markering af en sætning der er årsagsangivende satellit, og altså baggrund. Det er spidsfindigt, men ræsonnementet holder ikke, hvad der fremgår af at (25) og (27) er uproblematiske, medens (26) strider mod almindelig logik:

25) Vi kom for sent til lufthavnen og nåede ikke flyet

26) *Vi nåede ikke flyet og kom for sent til lufthavnen

27) Skønt vi kom for sent til lufthavnen, nåede vi alligevel flyet (det var forsinket)

Ifølge almindelig erfaring er det når eller efter at man ankommer til lufthavnen at man konstaterer om man faktisk kommer med sit fly eller ikke; og det at komme rettidigt opfattes sædvanligvis (af gode grunde) som forudsætning for at nå flyet. Tempusbrugen er i fuld overensstemmelse med den ekstrasproglige, men subjektive, virkeligheds beskaffenhed (jf. omtalen i § 4 af forholdet mellem sprog og virkelighed).

Pluskvamperfektum skulle altså have trækket [-tekstaktuel] i en narrativ tekst, modsat passato remoto og præsens, der tilskrives trækket [+tekstaktuel]. Det passer dog ikke på et ganske almindeligt eksempel som

28a) Prima di coricarmi, $m i$ diverti i nello studio di Ceriello a sfogliare alcuni antichi libri di astrologia. Come si sa, Masta è per eccellenza la capitale dell'astrologia, che vi si coltiva con un impegno e una serietà altrove sconosciuti. [...] Ceriello stesso, musicista di mestiere, è un appassionato dilettante di astrologia e per lunghe sere, a me decisamente scettico, a veva cercato di spiegare le meravigliose possibilità, almeno teoriche, di prevedere il futuro. (Buzzati, Le notti difficili, 51)

28b) Før jeg gik i seng, morede jeg mig [p.r.] med at bladre i nogle gamle bøger om astrologi i Ceriellos arbejdsvoerelse. Som bekendt er Masta astrologiens ubestridte hovedstad, den dyrkes dér med et engagement og en seriøsitet der ikke kendes andetsteds. [...] Ceriello, der er musiker af profession, er selv lidenskabeligt optaget af astrologi, og aften efter aften havde han for $\emptyset \emptyset \mathrm{g}$ at forklare mig, der var stoerkt skeptisk, de vidunderlige, $i$ det mindste teoretiske muligheder for at forudse fremtiden.

Her er det sætningerne i præsens der begrunder og dermed danner baggrund for sætninger dels i passato remoto (den første periode), dels i pluskvamperfektum (den sidste periode). Derimod er det indlysende at præsens må angive noget der er aktuelt 
fordi det gælder samtidigt med nutidsaksen, medens pluskvamperfektum præsenterer noget der ligger længere tilbage i tiden end det begivenhedsforløb der følger. Det er givet rigtigt at sætninger i pluskvamperfektum i de fleste tilfælde udgør en baggrund for noget - i en fortælling dog blot fordi det der præsenteres som 'allerede sket', nødvendigvis må virke som optakt (forhistorie) eller tilbagegreb, dvs. som en parentes i forløbet. Virkningen 'baggrund' er en simpel konsekvens af formens definition på grundlag af tid.

\section{MANGlende OVERENSSTEMMELSE MELLEM teMPUSMARKERINGER OG DEN EKSTRASPROGLIGE TID}

De definitioner jeg har givet ovenfor, synes undtagelsesfrit at dække en hvilken som helst forekomst af de italienske verbaltempora. Man vil ganske vist kunne finde eksempler på meget specielle og sjældne grænsetilfælde, hvad næppe nogen der arbejder med at beskrive grammatiske fænomener, kan undgå at komme ud for. Grammatikkens regler er jo ikke naturlove, men kan lejlighedsvis bruges utraditionelt og kreativt. Der er imidlertid to tilfælde hvor der sker visse forudsigelige afvigelser fra den måde hvorpå tempus lokaliserer en verbalhandling i forhold til nutidsaksen. Jeg har ovenfor lagt vægt på at verbalformerne p ræs e n ter e r en verbalhandling som lokaliseret og afgrænset på en nærmere bestemt måde, og altså ikke uden videre afspejler forhold i den ekstrasproglige virkelighed. Det vil naturligvis normalt være underforstået at den måde verbalhandlingen præsenteres på, er i overensstemmelse med virkeligheden. I det følgende skal vi se nærmere på hvordan afvigelser kan opstå.

\subsection{CONSECUTIO TEMPORUM MED OVERSAETNING + KOMPLETIV ELLER SPøRGENDE LEDSAETNING}

\subsubsection{OVERVERBUM I PRESENS}

Med oververbum i præsens (eller perfektum med vægt på konsekvenstilstanden) er alle tempora anvendelige i ledsætningen i overensstemmelse med de generelle regler for deres brug. Oververbets præsens (eller perfektum) forankrer netop ledsætningen i nutidsaksen. Et eksempel med oververbum i perfektum findes i (12), her forkortet til (29):

29a) Carlino ha detto a sua madre che stamani non a nd rà in ufficio

29b) Carlino har sagt til sin moder, at han ikke går [fut.] på kontoret til morgen

\subsubsection{OVERVERBUM I FUTURUM}

Også med oververbum i futurum (eller i futurum exactum) er alle tempora anvendelige i ledsætningen. Her foreligger der dog to muligheder:

A.

Den styrende futurum lokaliserer en akse der træder i nutidsaksens sted, således at ledsætningens tempus markerer temporal lokalisering i forhold til en fremtidsakse i stedet for til nutidsaksen. En ledsætning i præsens er da samtidig med fremtidsaksen, fx

30a) Si accorgerà che è tardi (cit. fra Vanelli 1991: 627)

30b) Han vil blive klar over [fut.] at det er sent 
Ledsætninger i perfektum, imperfektum, passato remoto og pluskvamperfektum betegner fortidighed i overensstemmelse med de enkelte formers definition, her blot $\mathrm{i}$ forhold til fremtidsaksen; i forhold til nutidsaksen kan der være tale om fremtidighed, $\mathrm{fx}$

31a) Fra vent'anni gli storici sa ranno tutti d'accordo che la guerra contro l'Irak, combattuta nel 2003, fu un tragico errore

31b) Om tyve år vil alle historikere voere enige om at krigen mod Irak, der blev udkoempet i 2003, var [p.r.] en tragisk fejltagelse [sagt før krigen]

Denne brug af passato remoto (og den tilsvarende af imperfektum) er et sjældent fænomen i praksis, men af betydelig teoretisk interesse. En hårdnakket og hidtil uimodsagt påstand, der hermed er gendrevet, går nemlig ud på at passato remoto altid skulle angive deiktisk fortid. ${ }^{12}$

B .

Ledsætningens tempus kan lokalisere verbalhandlingen direkte i forhold til nutidsaksen, dvs. uafhængigt af oververbet, $\mathrm{fx}$

32a) Ben presto capirai che quello ti ha ingannato

32b) Du vil meget snart forstå [fut.] at han har snydt dig

I dette tilfælde vil der kunne stå futurum exactum i ledsætningen; som altid ved sammensatte tempora er det konsekvenstilstanden der er lokaliseret, her i fremtiden, medens den forudgående afgrænsede handling kan ligge efter nutidsaksen, men også før, som i (33): ${ }^{13}$

33a) Se le cose vanno come lui pensa, allora si potrà dire che avrà visto bene

33b) Hvis tingene går som han tror, så vil man kunne [fut.] sige at han har set [fut.ex.] rigtigt

\subsubsection{OVERVERBUM I FORTID}

Med oververbum i fortid, herunder perfektum med dominans af den afgrænsede handling der går forud for konsekvenstilstanden, kan der principielt skelnes mellem de samme to muligheder som under $\S 8.1 .2$, men her er anvendelsen af type (B) stærkt indskrænket:

A.

Oververbet etablerer i langt de fleste tilfælde en sekundær akse der supplerer, men ikke ophæver nutidsaksen. Det indebærer (i) at ledsætningens tempus skal lokalisere den pågældende verbalhandling i relation til den sekundære akse, (ii) at der ikke opstår nogen konflikt med lokaliseringen i forhold til nutidsaksen. Dette resulterer i en symmetri mellem tempora, således at imperfektum i sit forhold til den sekundære akse svarer til præsens i forhold til nutidsaksen (se è ('er') og era ('var' limp.J) i eks. (16) og (17)); pluskvamperfektum svarer til perfektum, passato remoto og pluskvamperfektum; sammensat konditionalis svarer til futurum. 
Man bemærker forskellen i forhold til konstruktioner med oververbum i futurum (sml. § 8.1.2a): en fortidig akse der etableres af oververbet, kan ikke træde i nutidsaksens sted: man kan ikke sætte en kompletivsætnings verbal i præsens for at markere samtidighed med et oververbum i fortidstempus, eller i passato remoto for at markere fortidighed i forhold til et sådant oververbum. ${ }^{14}$ Dette er et blandt mange argumenter for at opdele tempussystemet i to grupper, hvor præsens og futurum står inden for samme gruppe: distinktionen [+/-fortid] er hierarkisk overordnet i forhold til distinktionen [+/-fremtid].

B .

I specielle tilfælde markerer ledsætningens tempus tid direkte i forhold til nutidsaksen. Det sker for det første ved brug af en præsens om samtidighed med nutidsaksen, hvilket (ligesom på mange andre sprog) forudsætter at verbalhandlingens lokalisering omfatter bå d e nutidsaksen og det styrende verbums fortid (i overensstemmelse med at den lokalisering man markerer ved præsens, kan omfatte en større eller mindre del af fortiden, jf. § 4). For det andet i kløvningslignende udtryk af typen Så skete [p.r.] det at han blev [p.r.] syg og Resultatet blev [p.r.] at hun meldte [p.r.] afbud.

Den indskrænkede brug af denne type viser atter at fortidstempora er udtryk for en dimension der er radikalt forskellig fra den der udtrykkes af nutids- og fremtidstempora: den under $\S 8.1 .2 \mathrm{~b}$ beskrevne type anvendes helt uden indskrænkninger.

C.

Et grænsetilfælde opstår når der skal udtrykkes en fortids fremtid der lokaliserer verbalhandlingen som fremtid og s å i forhold til nutidsaksen. Her finder man især sammensat konditionalis eller imperfektum, men ifølge Vanelli (1991: 626) også futurum, hvad der imidlertid kun demonstreres med oververber i perfektum. Da de imidlertid tillader at man lokaliserer ledsætningen ud fra nutidsaksen som beskrevet i § 8.1.1 ovenfor, kræver fænomenet en mere entydig belysning. Man kan sammenligne

34a) Già ieri sapevo che Marco sarebbe arrivato dopodomani

34b) Allerede i går vidste jeg [imp.] at Marco ville komme [sammensat kond.] i overmorgen

35a) Già ieri sapevo che Marco arriverà dopodomani

35b) Allerede i går vidste jeg [imp.] at Marco kommer [fut.] i overmorgen

Sammensat konditionalis og imperfektum resulterer i et forbehold m.h.t. om handlingen vil finde sted, der dog ikke - som hævdet af Vanelli (1991: 626) - er entydigt kontrafaktisk. Virkningen svarer til brugen af konditionalis om nutid/fremtid, og er dermed også i overensstemmelse med det princip jeg har formuleret under pkt. (A): nutidsaksen ophæves ikke trods etableringen af en sekundær akse i fortiden. - Hvad angår brugen af futurum som i (35), synes den at forudsætte at oververbet udtrykker en handling der kan forstås som fortsat i nutiden, hvad già ('allerede') tydeliggør.

En styrende imperfektum eller pluskvamperfektum der betegner en ved nutidsaksen afbrudt (konsekvens-) tilstand, eller en tilstand der fingeres at være afbrudt, kan dog uden problemer kombineres med futurum i ledsætningen, især i forbindelse med genoptagelse af handlingen, $\mathrm{fx}$ 
36a) Gli avevo chiesto dove ci inco ntrere mo con Carlo

36b) Jeg havde spurgt ham hvor vi skal mødes [fut.] med Carlo

\subsection{OVERFØRT BETYDNING AF TEMPUS}

Overført betydning af tempus er en meget hyppig form for afvigelse mellem indholdet af tempora og den ekstrasproglige tid; det er dog ikke muligt at give andet end en summarisk oversigt her. - Ligesom ved alle andre tilfælde af overført betydning beholder også tempusmorfemerne noget af deres egen grundbetydning, de bliver altså ikke slet og ret identiske med de former de erstatter (noget andet er at sprogudviklingen efterhånden kan føre til en grammatikalisering af en overført betydning). Jeg skal her foreslå at man skelner mellem metonymi og metafor i stedet for at tale om metaforisk tempusbrug generelt.

\subsubsection{TEMPUSMETONYMI}

Tempusmetonymi opstår ved en betydningsglidning hvor en form overtager en tilstødende kategoris betydning; det drejer sig især om præsens om noget netop indtruffet og derfor stadig aktuelt, eller om fremtid; tilsvarende gælder imperfektum i forhold til fortid. Ved metonymisk tempusbrug er der altid tale om en udskiftning af former inden for en af de to tempusgrupper, og om brug af en umarkeret form i stedet for en markeret.

Pittoresk imperfektum kan eventuelt betragtes som en 'aspektmetonymi'; der er tale om en imperfektiv fortid som udtryk for en reelt afgrænset begivenhed, $\mathrm{fx}$

37a) - È lui! - mormorò con viva emozione. - Era tempo! - Cinque minuti dopo un essere umano [...] si presentava davanti alla capanna. (Salgari, Le tigri di Mompracem, kap. 1)

37b) - Det er ham! - mumlede han, stoerkt bevoeget. - Det var på tide! - Fem minutter senere dukkede [imp.] en menneskelig skikkelse op foran hytten.

\subsubsection{TEMPUSMETAFORER}

Tempusmetaforer indebærer en mere drastisk betydningsændring, men dog stadig sådan at formernes grundbetydning ikke helt annulleres. Her er der enten tale om udskiftning af former mellem de to tempusgrupper, eller om at en markeret form bruges med en tidsreference der ikke-metaforisk udtrykkes med en umarkeret form:

- dramatisk (eller historisk) præsens. I virkeligheden er der tale om at hele tempussystemet bruges med udgangspunkt i en fingeret nutidsakse (der i hvert fald i klassiske narrative tekster knytter an til et fortidigt tidsplan i konteksten);

- modal imperfektum og pluskvamperfektum (på italiensk især i konjunktiv), om tankeeksperimenter; og

- modal futurum og futurum exactum om en formodning vedr. henholdsvis nutid og fortid. 


\section{KONKLUSION}

Jeg har i det foregående fremsat nogle generelle synspunkter vedrørende tempus og aspekt og konfronteret dem med andre. Jeg har endvidere foreslået en definition af de morfologiske former der udtrykker tempus- og aspektkategorien på italiensk, og diskuteret detailspørgsmål desangående, ikke mindst sådanne der af nogle forskere er blevet anset for problematiske. Jeg mener at have vist at de omtalte fænomener kan forstås som konsekvenser der lader sig udlede af nogle simple grundværdier. Det samme ville være tilfældet med adskillige andre fænomener som jeg har måttet lade ligge.

Definitionerne beviser deres generelle gyldighed ved at være egnede til at beskrive de kontekstuelle virkninger der opstår når det ene tempus virker sammen med det andet i hele tekster såvel som i konstruktioner inden for den enkelte sætning og periode. I sidstnævnte henseende er consecutio temporum en prøvesten, men jeg kunne også i højere grad have inddraget aktionsart og adverbialer. Man kan på dette felt som på andre konstatere hvordan sprogsystemet besidder en fundamental enkelhed, samtidig med at det kan bruges til at producere en uudtømmelig mangfoldighed af mening, der ikke opstår på trods af systemet, men på basis af dette. Det gælder såvel typiske, genkendelige mønstre som de helt individuelle karakteristika der udmærker mange litterære tekster.

Jeg mener endelig at have påvist at der næppe findes noget seriøst alternativ til at definere tempus som udtryk for tid. Beskrivelser der benytter andre begreber, kan nok bidrage med væsentlige iagttagelser, men løber ind i et væld af problemer med empiriske data som begreberne enten blot er uanvendelige på, eller som direkte strider mod selve kernen i de tilgrundliggende teorier.

\section{LITTERATUR}

Bach, Svend (1998/2000), "La definizione delle forme composte all'interno del sistema verbale dell'italiano", in: Blücher, Kolbjörn (red.) (2000), Atti del V Congresso degli Italianisti Scandinavi, Bergen 25-27 giugno 1998, Bergen: Seksjon for italiensk, Romansk institutt, Universitet i Bergen, pp. 147-157.

Bach, Svend (2001), "Un racconto al passato remoto: Invernale di Guido Gozzano", (Pré)publications, Nr. 183 (2001), pp. 7-18.

Bach, Svend (2003a), "Apostrofe som lyrisk indslag i fortællinger", (Pré)publications, Nr. 189 (2003), pp. 36-47.

Bach, Svend (2001/2003b), "Usi del presente nei testi narrativi", in: Egerland, Verner, Eva Wiberg (red.) (2003), Atti del VI Congresso degli Italianisti Scandinavi 16-18 agosto 2001, Lund: Romanska institutionen, Lunds Universitet, pp. 239-250.

Bach, Svend, Jørgen Schmitt Jensen (1990), Større Italiensk Grammatik, København: Munksgaard, §§ 313-356 og §§ 435-446.

Benveniste, Émile (1959), "Les relations de temps dans le verbe français", in: Benveniste, Émile (1966), Problèmes de linguistique générale, vol. 1, Paris: Gallimard, pp. 237-250.

Bertinetto, Pier Marco (1986), Tempo, aspetto e azione nel verbo italiano, Firenze: Presso l'Accademia della Crusca. 
Bertinetto, Pier Marco (1991), "Il verbo", in: Renzi, Lorenzo, Giampaolo Salvi (eds.) (1991), Grande grammatica italiana di consultazione, vol. II, Bologna: il Mulino, kap. I, pp. 13-161.

Ducrot, Oswald, Jean-Marie Schaeffer (1995), “Temps dans la langue”, in: Ducrot, Oswald, Jean-Marie Schaeffer, avec la collaboration de Marielle Abrioux et al. (1995), Nouveau dictionnaire encyclopédique des sciences du langage, Paris: Editions du Seuil, pp. 682-696.

Herslund, Michael (1987), "Catégories grammaticales et linguistique textuelle: la catégorie du temps en français", Cebal, no. 10 (1987), pp. 89-108.

Korzen, Iørn (2002), "Il Trapassato Prossimo in un'ottica pragmatico-testuale", in: Jansen, Hanne et al. (eds.) (2002), L'infinito \& oltre. Omaggio a Gunver Skytte, Odense: Odense University Press, pp. 203-226.

Petersen, Jürgen H. (1992), "Erzählen im Präsens. Die Korrektur herrschender TempusTheorien durch die poetische Praxis der Moderne", Euphorion, 86 (1992), pp. 65-89.

Skårup, Povl (2001), "Les valeurs temporelles des temps verbaux du français moderne et ancien", Revue Romane, 36/2 (2001), pp. 207-234.

Squartini, Mario (1999), "On the Semantics of the Pluperfect: Evidence from Germanic and Romance", Linguistic Typology, 3 (1999), pp. 51-89.

Vanelli, Laura (1991), "La concordanza dei tempi", in: Renzi, Lorenzo, Giampaolo Salvi (eds.) (1991), Grande grammatica italiana di consultazione, vol. II, Bologna: il Mulino, kap. XII, pp. 611-632.

Vegnaduzzo, Stefano (1997), "Il piucchepperfetto: discorso indiretto e presupposizione", Rivista di linguistica, vol. 9 (1997), pp. 343-385.

Weinrich, Harald (1964/1971), Tempus. Besprochene und erzählte Welt, Stuttgart: Kohlhammer. 
NOTER

1 Jeg har beskæftiget mig med tempus/aspekt i litterære tekster især i Bach (2001, 2003a) samt (2003b).

2 Måske har han det i tankerne at fortælling er envejskommunikation, hvor afsender- og modtagerrollerne ligger fast, således at kampen om at komme til orde er indstillet.

3 Ikke blot tekstens Guido, men også Komediens kommentatorer har haft problemer med at forstå dette sted. Man hælder dog nu om stunder til at mene at relativet cui er brugt dativisk med iboende korrelat og betyder 'til en som', med reference til Beatrice. Guido har vraget den kristne tro på sjælens udødelighed (som Beatrice står som allegori for), og Dante forsøger nu på en hensynsfuld og dermed også vag måde at forklare faderen hans vildfarelse.

4 Størstedelen af eksemplet findes i Bach/Schmitt Jensen (1990, § 340.2). Oversættelsen er foretaget af Olivia de Masi.

5 Passato remoto udtrykker perfektivt aspekt svarende til fransk passé simple. Se $§ 4$.

$6 \quad$ Hvilket er almindeligt den dag i dag i litterære fortællinger og memoirer. Et godt eksempel er Brigitte Bardots erindringer, hvori brugen af passé simple forbindes med alle de subjektive træk som formen ifølge Benveniste skulle være uforenelig med.

7 Jeg vil herefter bruge udtrykket 'verbalhandlingen' (som overbegreb for 'tilstand', 'proces' og 'begivenhed') om indholdet af et verbum (med fleksiv) + dets valensled.

8 Herslund (1987) mener derimod at præsens' manglende koekstensivitet med ytringstidspunktet er et problem og i lighed med (3) et argument for at opgive tanken om at tempus primært udtrykker tid.

9 Et eksempel findes også i den anden replik i eks. (37): E ra tempo (Det var [imp.] på tide).

10 "le plus important peut être l'un ou l'autre" (Skårup 2001: 208).

11 Ducrots behandling af usammensat tempus er ikke mindre problematisk: Perfektivt aspekt skulle i dette tilfælde angive en verbalhandling der ligger inden for 'thème temporel', medens imperfektivt aspekt skulle bruges om verbalhandlinger der har større udstrækning end, eller som er koekstensive med 'thème temporel'. En verbalhandling vil dog ofte skulle have perfektivt aspekt hvis den er koekstensiv med et angivet tidsrum. Jf. følgende eksempel, hvor subjektet udgør et 'thème temporel', der ved passato remoto karakteriseres i sin helhed:

[...] l'anno seguente [...] fu l'anno di una frase che diventò un emblema (Tabucchi, Piccoli equivoci, p. 10)

[...] det følgende år var [p.r.] året hvor der blev sagt [egentlig med] en saetning der blev symbolsk

Valget mellem passato remoto og imperfektum kan her forstås ud fra en succession der generelt forudsætter trækket [+afgrænset], og som i det konkrete tilfælde ligger i seguente ('følgende') og den større kontekst.

12 Bertinetto (1986: 429). Der meddeles intet om imperfektum, formentlig fordi denne form af andre grunde kan bruges om nutid og fremtid, jf. pkt. 8.2.

13 Citeret fra Bertinetto (1986: 509). Det samme slås fast i Bertinetto (1991: 126). If. Vanelli (1991: 631) (altså inden for rammerne af det samme kollektive værk) hævdes det derimod at en kompletivsætning ikke kan stå i futurum exactum efter et oververbum i futurum.

14 Et par afvigende og usædvanlige eksempler med passato remoto er dog citeret i Bach/Schmitt Jensen (1990, § 437, 4b). 